\section{B A Institute of \\ YK Business Administration \\ 六下 \\ Karachi \\ Leadership and Ideas for Tomorrow}

Business Review

Volume 2 Issue 2 July-December 2007

7-1-2007

\title{
Family functioning as a risk factor in the development of juvenile delinquency
}

\author{
Zeenat Ismail \\ Institute of Business Administration, Karachi, Pakistan \\ Zaeema Riaz \\ Department of Psychiatry, Liaquat National Hospital, Karachi, Pakistan
}

Follow this and additional works at: https://ir.iba.edu.pk/businessreview

Part of the Child Psychology Commons, Counseling Psychology Commons, Experimental Analysis of Behavior Commons, Family, Life Course, and Society Commons, and the Personality and Social Contexts Commons

(c) (1)

This work is licensed under a Creative Commons Attribution 4.0 International License.

\section{Recommended Citation}

Ismail, Z., \& Riaz, Z. (2007). Family functioning as a risk factor in the development of juvenile delinquency. Business Review, 2(2), 47-66. Retrieved from https://doi.org/10.54784/1990-6587.1389

This article is brought to you by iRepository for open access under the Creative Commons Attribution 4.0 License and is available at https://ir.iba.edu.pk/businessreview/vol2/iss2/4. For more information, please contact irepository@iba.edu.pk. 


\title{
ARTICLE
}

\section{Family Functioning as A Risk Factor in The Development of Juvenile Delinquency}

\author{
Zeenat Ismail \\ Institute of Business Administration, Karachi, Pakistan
}

Zaeema Riaz

Department of Psychiatry, Liaquat National Hospital, Karachi, Pakistan

\section{ABSTRACT}

The purpose of the present research was to determine the difference between the family functioning of juvenile delinquents and non delinquents. After detailed literature review it was hypothesized that score on the variable of Communication, Rigidity in Value and Norms, Affective Expression and Parental Control among family members of juvenile delinquents will be high as compared to non delinquents. Sample of the present research consisted of 240 adolescents divided into two groups of 120 delinquents and 120 non-delinquents from lowsocioeconomic status. Family Assessment Measure-III was administered in order to measure level of Communication, Value and Norms, Affective Expression and Parental Control among the family members of juvenile delinquents. \{-test was calculated in order to determine the difference in Communication, Value and Norms, Affective Expression and Parental Control among families of juvenile delinquents and non delinquents. The results showed significant differences on the variable of Communication, Value \& Norms, Affective Expression and Parental Control between the family members of delinquents and non delinquents.

\section{INTRODUCTION}

Juvenile delinquency is an emphasized, nebulous legal and social label for a wide variety of law and norm violating behaviors. Legally, a juvenile delinquent is one who commits an act defined by law as illegal and who is adjudicated "delinquent" by an appropriate court. The legal definition is usually restricted to persons under 18 , but states vary in their age distinctions (Bartol \& Bartol, 1986).

According to Schwartz and Johnson (1985) the term Delinquency is a legal one; used to refer to juvenile (usually under the age of 18) who has committed an act that would be considered illegal for an adult.

Families are one of the strongest socializing forces in life. They teach children to control unacceptable behavior, to delay gratification, and to respect the rights of others. Conversely, families can teach children aggressive, antisocial, and violent 
behavior (Wright \& Wright, 1994).

One of the most important influences upon the adolescent is the emotional climate of the family (Parish et aI, 1981). Some families evidence a prevailing mood of gaiety, joy, optimism and happiness. Other families reflect a climate of fear, depression, cynicism and hostility. The happier the parents and the more positive the home climate, the more beneficial the effect on growing children. The best adjusted children are those who grow up in happy homes where adolescents and parents spend pleasurable time together (McMillan \& Hiltonsmith, 1982). Numerous research studies emphasize the positive relationship between marital adjustment, family happiness, family solidarity, family cohesiveness, family cooperation and nondelinquency.

Social scientists generally agree that the family provides the most important social contact in the child's early life. In particular, the family is important in many theoretical positions on delinquency. Various family characteristics have been linked to the misconduct of adolescents. Hirschi (1969) analyze self-reported delinquency among 4077 junior and senior high school students (stratified by race and sex) in California found an association between delinquency and several measures of family relationships, such as Affectional identification with parents, intimacy of communication, internalization of norms, and parental involvement. Hirschi found that delinquency was inversely related to the bonds of attachment within the juvenile's family (Shoemaker, 1990).

In another study of over 900 adolescents aged 12-19, Cernkovich and Giordano (1987) concluded that seven different "family interaction patterns" have various impacts on self-report delinquency. These patterns are both indirect (emotional and communicative factors) and direct (control and supervising behaviors).

Canter (1992) also studied the family aspect of delinquency and found that family bonds are modestly correlated with delinquency and with evidence of their greater association among males in many cases. Social service professionals who frequently come into contact with children must be especially vigilant in order to detect the presence of any of the possibly contributory conditions mentioned above and to refer families to appropriate sources of assistance as early as possible. Generally speaking, the relationship between family conflict and delinquency is significant. There are many types of family conflict but the absence of communication and the inability to solve problems are two of the most fundamental forms relative to future delinquency. The nature of these conflicts is cyclical in that communication and problem-solving breakdowns increase the incidences of delinquency which in turn increase the stress and conflict levels within the family leading to more instances of deviant behavior (Smith \& Stem, 1997). 
Communication plays a big role in how the family functions. Clark and Shields (1997) state that the importance of positive communication for optimal family functioning has major implications for delinquent behavior. Intimacy of communication between parent and child is another element of attachment that decreases the child's likelihood to become involved in delinquent criminal behaviors. The child demonstrates this by sharing his thoughts and feelings and talking over his future plans with his parents (Hirschi, 1969).

One key to harmonious parent-youth relationship is communication (Faw \& Goldsmith, 1980). According to Hirschi (1969), it is not the simple fact of communication with parents, but the focus of this communication that is crucial in affecting the likelihood that a child will recall his parents, when and if, a situation of potential delinquency arises.

Weintraub \& Gold, (1991) found that both communication and monitoring were related to adolescent's deviance and that two variables contributed in an additive and interactive (for e.g. High level of communication and monitoring predicted lower levels of deviance) fashion to adolescent deviance.

For adolescents, two components of parenting have been identified as important, monitoring (i.e., the extent to which a parent knows where an adolescent is and what she or he is doing) and positive communication the extent to which a parent and adolescent listen to what each other is saying, for example poor parent-adolescent communication has been linked to more delinquency (Henggler, 1989) \& greater deviance (Stewart, \& Zaenglin-sengee, 1984), whereas higher levels of monitoring have been associated with lower levels of adolescent deviance (Lamborn., Dornbusch,\& Steinber,1996)

As children approach adolescence, interaction with parents is based more on conversation negotiation and joint decision-making than on the ability of parents to regulate their behavior unilaterally (Maccoby, 1984).

Preadolescents and adolescents seldom dispute parent's authority to make rules unilaterally and should not have such low expectations of their abilities to comply (Hunter, 1984). Perhaps, therefore, family conflicts facilitate communication and adolescent autonomy by promoting open discussions of the parent's reasons and adolescents protest over their parent's unilateral authority and demands Youniss, 1988; Youniss \& Smoller, 1985).

The major focus of attention has been on the link between attachment and the adequacy of socialization, the internalization of norms. As is well known, the emotional bond between the parent and the child presumably provides the bridge across which pass parental ideals and expectations. If the child is alienated from the 
parent, he will not learn or will have no feeling for moral rules, he will not develop an adequate conscience or superego (Hirschi, 1969).

To be accepted by most groups and organizations, children must learn basic prescribed values, norms, and roles. Experienced persons such as parents, older family members, neighbors, and teachers must serve as guides and instructors while children awkwardly fill new roles in recurring social situations, a process of learning called "socialization." Persons who teach children about values, norms and roles are called "role models" (Shibutani, 1986). Role models tolerate and correct the mistakes of younger persons who usually fill relatively simple roles in groups until they can learn to enact more complex and varied roles.

The social learning tradition generally conceptualized child morality as conformity to the norms of adult behavior (Bandura, 1977; Sears, Maccoby, \& Levin, 1957; Sears, Rau, \& Alpert, 1965).

Two parental factors have been viewed as having a significant impact on the developing individual: the nature of the affectional interaction between the parents and their offspring and the type of parental discipline (Becker, 1964: Hoffman, 1970: Tutt, 1974). A larger proportion of parents of delinquents have reported that one or both parents used disciplinary practices that were erratic, extremely lax, or umeasonably rigid.

Effective delinquency prevention comes "from a warm, loving, stable family, [where] the child learns that people are friendly, worth knowing and can be depended upon." Delinquency is most likely "when a family is cold, despairing, rejecting, or neglectful, [because] the child learns distrust, hostility, or dowmight hatred of people" (National Conference on Prevention and Control of Juvenile Delinquency, 1974).

Family life is our first school for emotional learning; in this intimate cauldron we learn how to feel about ourselves and how others will react to our feelings; how to think about these feelings and what choices we have in reacting; how to read and express hopes and fears. This emotional schooling operates not just through the things that parents say and do directly to children, but also in the models they offer for handling their own feelings and those that pass between husband and wife ... How parents treat their children--whether with harsh discipline or empathic understanding, with indifference or warmth and so on--has deep and lasting consequences for the child's emotional life (Goleman, 1995 ).

According to Bratter, T.E., (1973) in delinquent's family there is little or no affection, no curfews, no discipline and no relationship of any merit between parent and child. In general, those adolescents whose parents treated them firmly but with 
love and respect tended to be considerably less delinquent than those juveniles whose parents continually nagged or scolded them or treated them as pawns by making expressions of love or acceptance contingent on good behavior (Shoemaker, 1990).

Mothers who are themselves empathic, concerned and sympathetically responsive have the most empathic and self-regulating children (Eisenberg et a1., 1992; Eisenberg, Fabes \& Murphy, 1996; Eisenberg \& McNally, 1993). Children are also more likely to show adaptive, sympathetic behaviors when (a) family discussions focus on "gentle" negative emotions such as sadness and grief, (b) when mothers engage in other-oriented induction by drawing links between their children's own experiences and the distress experiences of other people, and (c) when mothers express approval of children's sympathetic acts (Eisenberg et a1., 1992).

Methods of control or processes and forms of discipline can play a part of development of delinquent child. Erickson states there are eight stages of development that a child must go through so as to become a responsible adult. Monitoring becomes increasingly important as children move into adolescence and spend less time under the direct supervision of parents or other adults and more time with peers. Previous research found that coercive parenting and lack of parental monitoring contributes not only directly to boys' antisocial behaviors, but also indirectly as seen in the contribution to their increased opportunity to associate with deviant peers, which is predictive of higher levels of delinquent acts (Kim, et a1., 1999). Gray-Ray and Ray (1990), The findings of this study is in accord with social control theorists' who suggest that delinquency is made possible by a weakening or severing of the bonds between the adolescent and his parents. All familial control variables had an inverse relationship on delinquency, with perceived parental rejection having the most significant effect.

Inconsistent discipline has been found as a significant, contributing factor to juvenile delinquency. Parents, who ignore inappropriate behavior, are negligent about consistently punishing all misbehaviors with pre-established punishments or who threaten punishment but don't follow through with it will raise children who are more likely to engage in delinquent behavior (Laub \& Sampson, 1998; Wells and Rankin, 1988).

Parents could extinguish their children's undesirable behavior through punitive discipline (e.g., Parke, 1975; Patterson, 1975) by attempting to detemiine whether or not parent's disciplinary styles have a discernible impact not only on their children's current behavior, but also on future behavior in a variety of settings.

Lytton and Zwirner (1975) found that compliance with immediate parental demands was maximized by power-assertive techniques involving physical control, 
punishment, and commands whereas compliance occurred less frequently following positive action or reasoning. Richardson, et al (1989) states that there was a strong correlation between lack of parental supervision and substance use independent of family structure.

After detailed literature review and keeping in view Pakistani culture the following hypotheses were framed. It may be noted that higher scores on a given variable are indicative of greater dysfunction.

1) Scores on the variable of communication among family members of Juvenile delinquents would be higher than non-delinquents.

2) Scores on the variable of control among family members of Juvenile delinquents would be higher than non-delinquents.

3) Scores on the variable of Rigidity in following values and norms among family members of Juvenile delinquents would be higher than nondelinquents.

4) Scores on the variable of affective expression among family members of Juvenile delinquents would be higher than nondelinquents.

\section{METHOD}

\section{SAMPLE}

A cluster sampling method was used for the present research and two samples of participants were recruited from Karachi. The sample consisted of 240 adolescents divided into two groups of 120 delinquents and 120 non-delinquents from low socioeconomic status. The first sample consisted of male adolescents (delinquents) who were all charged with the commission of a delinquent act and was enrolled in the Youthful Offender Industrial School Karachi with the length of imprisonment less than 1 month. The second sample consisted of adolescents (nondelinquents) from several urban high schools located in different lower class areas of Karachi having no history of being charged with the commission of a delinquent act. The ages of the participants in both samples ranged from 12 years to 18 years with a mean age of 15 years (delinquents $=15.85$, non-delinquents $=14.25$ ). The entire sample comprised of adolescents living in two parent families.

\section{PROCEDURE}

The entire sample was drawn from low socioeconomic class determined on the basis of household income and expenditure survey (2001). The sample was divided in two groups i.e., delinquents and non delinquents. First sample of subjects were selected from the Youthful Offender Industrial School Karachi. For the first sample of delinquents, after getting permission from authorities, consent of Participant was also taken and then questionnaires were administered individually. Before the 
administration of psychological tests the researcher established rapport with the children individually. General scale of Family Assessment MeasureIII( Skinner, Stenhauer \& Santa Barbara, 1995) was administered in order to measure level of communication and value and norms prevailing in a family. Dyadic scale of the same test was used to assess Parental control and affective expression in the families of juvenile delinquents. The examiner had to read aloud the questions and mark the responses for children, as many of them were uneducated.

Second sample was drawn from various schools located in different urban areas of Karachi (Pakistan). Consent was taken from the principals and participants of each school. Similar procedure of rapport development and administration was followed as in the case of first sample.

\section{URDU TRANSLATIONS}

Epidemiological studies have focused on the cultural relevance and clinical usefulness of translations of Western scales into non-western languages. This translation is to be an interim measure, until the equivalents of such instruments are developed indigenously (Munford, 1990; Nayani 1990).

In order to facilitate the understanding of the children, the above mentioned scales were translated into Urdu. Few modifications were done according to the requirement of Pakistani culture. The translation procedure used for each of the scales involved the input of 6 experts at various stages of translation. The scales were given to different individuals, who were proficient in both Urdu and English. Three individuals were required to translate the items into Urdu and then three other individuals were asked to translate them back to English.

\section{STATISTICS}

t-test for independent sample was computed to test the significance of difference between the means of communication, value and norms, affective expression and control.

Further Binary logistic regression model was applied to determine the predicting effect of the variables of family functioning (communication, affective expression, control (Parental) and rigidity in value and norms) between delinquents and non delinquents. 


\section{RESULTS}

Table No 1

Table Showing the difference in the level of Communication among family members of Delinquents and Non-Delinquents

\begin{tabular}{|c|c|c|c|c|c|c|c|c|c|}
\hline \multirow[t]{2}{*}{ Groups } & \multirow[t]{2}{*}{$\mathrm{N}$} & \multirow[t]{2}{*}{ Mean } & \multirow[t]{2}{*}{ St.Deviation } & \multirow[t]{2}{*}{$\begin{array}{c}\text { Std. Error } \\
\text { Mean }\end{array}$} & \multirow[t]{2}{*}{$\mathrm{df}$} & \multirow[t]{2}{*}{$\begin{array}{c}\text { Sig. } \\
\text { (2-tailed) }\end{array}$} & \multirow[t]{2}{*}{$\mathrm{t}$} & \multicolumn{2}{|c|}{$\begin{array}{c}95 \% \\
\text { Confidence } \\
\text { Interval of the } \\
\text { difference } \\
\end{array}$} \\
\hline & & & & & & & & Lower & Upper \\
\hline Delinquents & 12020 & 6.5417 & 2.2451 & .2049 & \multirow{3}{*}{238} & \multirow{3}{*}{.000} & \multirow{3}{*}{4.117} & \multirow{3}{*}{.5997} & \multirow{3}{*}{1.7003} \\
\hline & & & & & & & & & \\
\hline \begin{tabular}{|l|} 
Non- \\
Delinquents
\end{tabular} & 12020 & 5.3917 & 2.0795 & . 1898 & & & & & \\
\hline
\end{tabular}

$\mathrm{t}=4.117, \mathrm{df}=238, \mathrm{P}<0.05$ indicate significant difference between Delinquents and Non-Delinquents on the variable of Communication.

Table No. 2

Table Showing the difference in the level of Values and Norms among family members of Delinquents and Non-Delinquents

\begin{tabular}{|c|c|c|c|c|c|c|c|c|c|}
\hline \multirow[t]{2}{*}{ Groups } & \multirow[t]{2}{*}{$\mathrm{N}$} & \multirow[t]{2}{*}{ Mean } & \multirow[t]{2}{*}{ St.Deviation } & \multirow[t]{2}{*}{$\begin{array}{c}\text { Std. Error } \\
\text { Mean }\end{array}$} & \multirow[t]{2}{*}{$\mathrm{df}$} & \multirow[t]{2}{*}{$\begin{array}{c}\text { Sig. } \\
\text { (2-tailed) }\end{array}$} & \multirow[t]{2}{*}{$\mathrm{t}$} & \multicolumn{2}{|c|}{$\begin{array}{c}95 \% \\
\text { Confidence } \\
\text { Interval of the } \\
\text { difference }\end{array}$} \\
\hline & & & & & & & & Lower & Upper \\
\hline Delinquents & 120 & 6.9167 & 2.6555 & .2424 & \multirow{2}{*}{238} & \multirow{2}{*}{.000} & \multirow{2}{*}{4.743} & \multirow{2}{*}{.8868} & \multirow{2}{*}{2.1466} \\
\hline $\begin{array}{l}\text { Non- } \\
\text { Delinquents }\end{array}$ & 120 & 5.40 & 2.2840 & .2085 & & & & & \\
\hline
\end{tabular}

$\mathrm{t}=4.743, \mathrm{df}=238, \mathrm{P}<0.05$ indicate significant difference between Delinquents and Non-Delinquents on the variable of Values and Norms.

Table No. 3

Table Showing the difference in the level of Affective Expression among family members of Delinquents and Non-Delinquents

\begin{tabular}{|c|c|c|c|c|c|c|c|c|c|}
\hline \multirow[t]{2}{*}{ Groups } & \multirow[t]{2}{*}{$\mathrm{N}$} & \multirow[t]{2}{*}{ Mean } & \multirow[t]{2}{*}{ St.Deviation } & \multirow[t]{2}{*}{$\begin{array}{c}\text { Std.Error } \\
\text { Mean }\end{array}$} & \multirow[t]{2}{*}{ df } & \multirow[t]{2}{*}{$\begin{array}{c}\text { Sig. } \\
\text { (2-tailed) }\end{array}$} & \multirow[t]{2}{*}{$t$} & \multicolumn{2}{|c|}{$\begin{array}{c}95 \% \\
\text { Confidence } \\
\text { Intervalofthe } \\
\text { difference }\end{array}$} \\
\hline & & & & & & & & Lower & Upper \\
\hline Delinquents & 120 & 7.3500 & 2.2960 & .2096 & \multirow[b]{2}{*}{238} & \multirow[b]{2}{*}{.003} & \multirow[b]{2}{*}{3.820} & \multirow[b]{2}{*}{.5125} & \multirow[b]{2}{*}{1.6041} \\
\hline $\begin{array}{l}\text { Non- } \\
\text { Delinquents }\end{array}$ & 120 & 6.2917 & 1.9848 & .1812 & & & & & \\
\hline
\end{tabular}

$\mathrm{t}=3.820, \mathrm{df}=238, \mathrm{p}<0.05$ indicate significant difference among Delinquents and NonDelinquents on the variable of Affective Expression. 
Table No. 4

Table Showing the difference in the level of Control among family members of Delinquents and Non-Delinquents

\begin{tabular}{|c|c|c|c|c|c|c|c|c|c|}
\hline \multirow[t]{2}{*}{ Groups } & \multirow[t]{2}{*}{$\mathrm{N}$} & \multirow[t]{2}{*}{ Mean } & \multirow[t]{2}{*}{ St.Deviation } & \multirow[t]{2}{*}{$\begin{array}{c}\text { Std.Error } \\
\text { Mean }\end{array}$} & \multirow[t]{2}{*}{$\mathrm{df}$} & \multirow[t]{2}{*}{$\begin{array}{c}\text { Sig. } \\
\text { (2-tailed) }\end{array}$} & \multirow[t]{2}{*}{$\mathrm{t}$} & \multicolumn{2}{|c|}{$\begin{array}{c}95 \% \\
\text { Confidence } \\
\text { Interval of the } \\
\text { difference }\end{array}$} \\
\hline & & & & & & & & Lower & Upper \\
\hline Delinquents & 120 & 7.1500 & 2.4586 & .2244 & & & & & \\
\hline $\begin{array}{l}\text { Non- } \\
\text { Delinquents }\end{array}$ & 120 & 6.5583 & 2.1175 & .1933 & & t & & & \\
\hline
\end{tabular}

$\mathrm{t}=1.997, \mathrm{df}=238, \mathrm{P}<0.05$ indicate significant difference between Delinquents and Non-Delinquents on the variable of Control. The mean score of Adjustment of these two groups do not differ significantly.

Table 5

Classification Table

\begin{tabular}{|c|c|c|}
\hline $\mathrm{G}$ & $\mathrm{df}$ & p-value \\
\hline 32.515 & 4 & 0.000 \\
\hline
\end{tabular}

Table 6

Logistic Regression with Communication, Values \& Norms, Affective Expression and Parental Control as predictor of delinquency

\begin{tabular}{|l|c|c|c|c|}
\hline & B & S.D & Z & Sig \\
\hline Constant & -2.7156 & 0.6146 & -4.42 & 0.000 \\
Communication & 0.15519 & 0.07346 & 2.11 & 0.035 \\
Values \& Norms & 0.17838 & 0.06267 & 2.85 & 0.004 \\
Affective Expression & 0.14394 & 0.07126 & 2.02 & 0.043 \\
Parental Control & -0.04105 & 0.06858 & -0.60 & 0.549 \\
\hline
\end{tabular}

$\mathrm{Z}=2.11,2.85,2.02, \mathrm{P}<0.05$ indicate Communication and Values \& Norms and Affective Expression respectively as Significant predictors and Parental $\operatorname{Control}(Z=-0.60, P>0.05$. as insignificant predictor of Delinquency.

\section{DISCUSSION}

Juvenile delinquency is an important problem, which needs immediate attention of social scientists. The number of crimes has increased and the problem is being widely discussed. However the discussions most often concentrate merely on the fact itself and its scale, and tend to forget the factors that determine the situation. To better understand why young people commit crimes it is essential to know the factors that determine juvenile delinquency. 
There has been growing interest in how variations in family process may be differentially related to emotional and behavioral problems in children. Family is the first institution of children's socialization and one of the most influential agents, determining the formation of a personality; the family transmits social values, improves morality and proper behavior. Children of dysfunctional families are based primary on the assumption that they possess certain maladaptive characteristics. According to Beavers and Hampson (1990) family dysfunction is based on the interactive patterns in the family, with emphasis on how well the family can organize and manage itself.

Previous research has shown that problems in family functioning are linked to the development of antisocial, aggressive and delinquent behavior in children and adolescents (Snyder \& Patterson, 1987). For e.g. (a) families of delinquents have been found to be less warm, to be more conflict ridden and to demonstrate poorer communication skills than families of non delinquents (Alexander, 1973, Patterson, 1986); (b) parents of delinquent youth monitor their children less effectively than parents of non-delinquents (Patterson \& Stouthamer-Loeber, 1984); and (c) parents of oppositional boys have been found to back down in response to their children's non-compliant, hostile behavior effectively reinforcing such behavior (Patterson, 1986).

An analysis of the results (Table No.1, 2, 3 \& 4) and graphs (a,b,c,d) reveal that there is a significant difference on the variable of Communication $(\mathrm{t}=4.117$, $\mathrm{df}=238, \mathrm{P}<.05)$, Value \& Norms $(\mathrm{t}=4.743, \mathrm{df}=238, \mathrm{P}<.05)$, Affective Expression $(\mathrm{t}=3.820, \mathrm{df}=238, \mathrm{P}<.05)$ and Parental Control $(\mathrm{t}=1.997, \mathrm{df}=238, \mathrm{P}<.05)$, among the family members of delinquents and non delinquents.

Further results (Table No.5, 6 \& 7) of Binary Logistic Regression reveal that high scores on family functioning variables predict delinquent behavior in adolescence with Communication, value and norms and affective expression as having more impact than parental control.

Generally speaking, the relationship between family conflict and delinquency is significant.

There are many types of family conflict but the absence of communication and the inability to solve problems are two of the most fundamental forms relative to future delinquency. The nature of these conflicts is cyclical in that communication and problem-solving breakdowns increase the incidences of delinquency which in turn increase the stress and conflict levels within the family leading to more instances of deviant behavior (Smith \& Stem, 1997).

It is particularly interesting that past studies focused on communication skills, because communication is typically considered the basic building block of 
relationships. Because communication skills are learned, it seems plausible to expect that children raised in dysfunctional families learned dysfunctional communication patterns that may be effecting their communication in current relationships. Hadeley et aI, (1993) also reported that the degree of family dysfunction was significantly related to internalized shame, object relation deficits, presence of addiction, and emotional problems. It therefore appears that dysfunction in the family of origin may effect several domains of an individual's life, two of which are problem solving communication, and global distress in intimate relationships.

In the present study it was hypothesized that Juvenile delinquents will score high on the variable of communication as compared to non delinquents indicating ineffective communication patterns on the part of delinquent's families. The results of the present research were consistent with the hypothesis formulated and previous studies and theories. Control theory assumes that the family bond that is created by positive family communication by parents and other responsible adults is a major deterrent to crime. The stronger this family bond, the more likely the youth is to take that bond into account when and if he or she contemplates a criminal act. When adolescents can communicate openly with family, they refrain from delinquency to avoid embarrassing, disappointing, or hurting their parents. Poor parent-adolescent communication has been linked to more delinquency (Henggeler, 1989) and general deviance (Stewart \& Zanglein-Senger, 1984). Communication may serve to improve the parent adolescent relationship, thus increasing the internalization of parental values and decreasing deviance, whereas monitoring may serve to decrease deviance directly through parental control of adolescent's activity (Forehand, Miller, Dutra, \& Chance, 1997).

Many of the delinquents in the current study reported that they cannot communicate with their fathers instead they share their feelings (if they do) with their mothers as they do not have time for their children or they (adolescents) are scared of their fathers. Their fathers have always discouraged them to say anything in front of them and kept a distance. Dodson (1977) describes examples of dysfunctional patterns of behavior and communication in families. For example, every family develops unspoken rules about who can talk to whom, and about what one may talk. In some families, this rule may be so dysfunctional that a child who wants father to know something tells mother, and mother tells father. It is easy to predict the quality of the relationship between father and his child.

Some parents feel threatened when their adolescents disagrees, doesn't accept their ideas, or tries to argue. Parents who refuse to talk and close the arguments by saying 'I don't want to discuss it, what I say goes' are closing the door to effective communication.

Both the parents and children find it difficult and frustrating to be unable to communicate adequately due to their life backgrounds and experiences. In was 
hypothesized that scores on the variable of rigidity in following Value and Norms among family members of delinquents will be higher as compared to non delinquents. Parents and their children commonly have different value systems and different perspectives. The children often complain that their parents are stubborn and outdated, while the parents are uncomfortable seeing their children behaving untraditionally. This causes mutual distress and tension. It is not merely the difference in value systems, but the uncertainty and confusion usually weaken the parental authority and make the situation worse. If a basic emotional bond together with fluent and adequate communication does not exist between parents and children, tension and conflict will arise in the relationship.

When the stresses are high and the support systems of the family are insufficient, the family may become isolated, enmeshed, or disengaged, and then conflict may occur in the family. Such conflicts may lead to crimes, drug abuse and the like. Communication limitation, unfamiliarity with values and beliefs or lifestyle of a family increases the risk of misconduct in children. Due to the family situation, youth may have trouble fitting into the mainstream or satisfying their social and emotional needs in the family, and they often join gangs that provide companionship and excitement but whose membership demands delinquent acts as an entrance requirement (Offer, Marohn, \& Ostrov, 1979). For this reason, it is important to see that an underage person would be correctly oriented in life and their negative experience would be as little as possible.

Parents and adolescents face a conflict of values. Sometimes the conflict is between parental and adolescent's values, but just as often the parents are experiencing value conflict within themselves just as the adolescents are. The adults are aware of value changes around them that sometimes conflict with the traditional values with which they have grown up. They have lost some of the idealism of their own youth; usually they have become more cynical and realistic and less certain about many things. At the same time adolescents are also questioning the values with which they have grown up; they are getting acquainted with new and different friends, some of whom have completely different values than they do. Adolescents start rethinking their values sometimes the new thoughts are shocking to parents, and never reassuring, because they remind the parents of their own confusion. The result is that adolescents make the adults feel even more uncertain. Adults may react with dogmatism ad authoritarian to convince both their adolescents and themselves that they are right. In Families of delinquents individual members function separately and autonomously with little family interdependence (McWhirter et al. 1998). In such families one common characteristic is parental inconsistency towards rules and the behavior of the children. Inconsistency may take various forms: 1) certain behaviors are permitted at one time but not at another, 2) what the child is told to do is inconsistent with what the child sees other family members doing, and 3) one parent may enforce a rule while the other parent allows for the breaking of the rule. 
Therefore it is important that parents must not adopt a rigid pattern to impose value and norms which they expect their children to follow.

Parental consistency with rules enforced in a strict, but fair manner is the discipline style that positively influences a child's social and emotional development. The family that continues to impose strict traditional values on its members is forced to strengthen family bonds in an attempt to cope with the unprecedented stress confronting it. If problems arise, the family is not in a position to make use of the helping facilities of its new community, nor is it able to adopt the new values. In the case of family members who no longer accept the family's values, arid lifestyle, the family becomes vulnerable and immobile which precipitates the loosening of boundaries to the point of disengagement and the ultimate vulnerability of all its members.

Studies have shown that what parents expect from their children also affects the likelihood of future delinquency. Typically parents who set high but reasonable standards of conduct have children who are less likely to commit crimes (Wilson, 1980; Laybourn, 1986). Parents must teach and encourage their children to behave within a certain set of clear and realistic expectations.

Now we will investigate and explore the importance of Affective Expression and Parental control processes associated with families and its role in the development of deviance behavior among Pakistani adolescence.

In the present study it was hypothesized that scores on the variable of Affective expression among family members of delinquents will be high as compared to non delinquents indicating unhealthy family functioning of the juvenile delinquents.

A vital element of communication is the expression of affect. Individual everywhere experience more or less warmth and affection at the hands of the people most important to them as they grow up (Rohner and Rohner, 1981) Rohner call these people "parents" although they are not necessarily mother and father. The warmth and affection (or its withdrawal) each of us has experienced as a child can be placed on a continuum the "warmth dimension" of parenting. One end of the warmth dimension is marked by the parental acceptance and the other end is marked by rejection. Parental acceptance which refers to the warmth, affection and love parents can give their children has two principle expressions: physical and verbal, physical expression of warmth and affection include hugging, fondling, caressing, approving glances, kissing, smiling and under such indication of endearment, approval, or support. Expressions of verbal warmth and affection include praising, complimenting, saying nice thing to or about a child, perhaps singing songs or telling stories to a young child, and the like. Children in most accepting families experience 
combination of all these behaviors. Even the warmth of parents however, is apt to get angry and impatient, or display other elements of rejection from time to time, although in some families children never know the satisfaction of parental affection or approval in any form.

Parental Rejection, which is defined conceptually as the absence or significant withdrawal of warmth, affection or love by parents towards children, lies at the opposite end of the warmth dimension. It takes three major forms (Rohner, 1975) (1) Hostility and aggression, (2) indifference and neglect (3) "undifferentiated rejection". Glueck, and Glueck, (1974) reported that the family life of delinquents was characterized by parental indifference or hostility and that offspring were less attached to their parents.

Children need love, affection to grow, to thrive, to develop. When it is lacking they will seek elsewhere ... gang membership. In many cases parents become concerned only when the delinquent action of their child is brought to their attention. If the parents or other family members of a child constantly criticize, put their children down by not replying to them or using sarcasm makes they feel rejected and inferior. These children then seek for acceptance elsewhere usually their peers and gets involved in delinquent activities. Emotional maltreatment include neglect by parents who focus on their own problems and ignore those of their children; who use guilt and other manipulations to control children's lives, who subject children to unpredictable mood swings due to alcoholism and other drug abuse; and who frequently demand that children assume adult care taking responsibilities (Forward, 1990).

The way parents control the behavior of their children has long been seen as an important predictor of children's later social and intellectual competence (Maccoby \& Martin, 1983). In the present study it was hypothesized that scores on the variable of Parental control in the family of juvenile delinquents will be higher as compared to non delinquents.

In addressing the issue of disciplinary practices, studies (Baumrind, 1990) of delinquent behaviors have repeatedly demonstrated a strong connection between inconsistent and erratic discipline and antisocial behaviors in children and adolescence. According to Nye(1958), parents reduce delinquency when they control their children's time away from home, choice of companions, and activities (Culliver, 1958).

Parents and adolescents are simultaneously facing an authority crisis. Parents hate to lose authority. For years their children have depended upon them for everything, their physical and emotional needs and guidance and advice. Now the adolescent strive for independence, for the right to govern their own lives and to make their own decisions. Parents have difficulties changing pattern of child guidance and often use 
inconsistent way of discipline. Either they become too rigid in controlling their children to the extent that they physically and verbally abuse them or on the other hand they do not even care where the child is. Inconsistent discipline has been found as a significant, contributing factor to juvenile delinquency. Parents who ignore inappropriate behavior, are negligent about consistently punishing all misbehaviors with pre-established punishments or who threaten punishment but don't follow through with it will raise children who are more likely to engage in delinquent behavior (Laub \& Sampson, 1998; Wells and Rankin, 1988).

The issue of how much control is enough and how much autonomy is too much is pertinent to populations at risk for disruptive, aggressive behavior problems (Dornbusch, et aI, 1985; Patterson \& Stouthamer-Loeber 1984). It has been demonstrated that when parents engage in hostile control, they communicate that hostility is an acceptable way of resolving interpersonal disputes (Patterson, 1986). Thus, the families of antisocial youth are caught in a "coercive trap", family members feel that they must either submit or attack. Either choice promotes the escalation of conflict and aggression. Several studies have linked child adolescent autonomy and risk for the development of psychological problems. For e.g. Feldman \& Rosenthal (1990), who studied differences in autonomy expectations across cultures, reported that expectations of early autonomy, among adolescents are associated with conduct problems. Ryan \& Lynch (1989) found that "emotional autonomy" among adolescents is associated with poor family functioning.

In the present study although there is a significant difference in the level of control among family members of delinquents and non delinquents it does not predict delinquency in the present research. In the Pakistani culture children are expected to be obedient toward their parents and they have been brought up in a manner that they have to consider their parents as all powerful and interfering in every matter of children. Sometimes there is even an order of authority among the children themselves, with younger children being expected to yield to older ones. Independent behavior on the part of a child is not encouraged. Respect for parents and other elders are seen as a basic virtue; children see others showing such respect, and soon acquire it themselves. There is often considerable warmth and care in the way parents and older members (e.g., grandparents) treat the younger ones, especially when they are very small. But they are looked after and consequently they are not expected to experiment for themselves.

Respect for parents and older relatives lasts through adulthood; parental authority continues to play a role in the child's life as long as the parents are alive. Parents and grandparents are treated with formal deference even after their children have actually taken control of their own lives. There is an established pattern of dependence for the child to seek advice and permission from parents when major issues confront their life, no matter what age the child has reached or what level of maturity. The family is 
the basic significant element of Pakistani culture. The individual's total life is dominated by the family relationships. Respect for the parents, extended family and elders are an important value in this society. Parents gain more respect and power, as they get older. In their older age, parents may retain their own residence and be looked after by their children or they may live with one of them.

Schooling and education which is the other significant factor where children further develop their mental programming. Children from the very beginning are controlled by either their parents or teachers. Teachers and classmates instill additional values, as they, too, are part of a culture that honors those values. In Pakistani culture, the parent child inequality is perpetuated by a teacher! student inequality, which caters to the need for dependence already well established in the student's mind. Teachers are treated with respect; students may have to stand up when they enter.

The educational process is teacher-centered; teachers outline the intellectual paths to be followed. In the classroom there is supposed to be a strict order with the teacher initiating all communication. Students in class speak up only when invited to; teachers are never publicly contradicted or criticized and are treated with deference even outside school. When a child misbehaves, the teacher involves the parents and expects them to help with getting the child in order. The educational system is highly personalized. Especially in the more advanced subjects at universities what is transferred is not seen as an impersonal 'truth' but as the personal wisdom of the teacher.

In Pakistani culture, corporal punishment at school is much more acceptable. It accentuates and symbolizes the inequality between teacher and student and is often considered good for the development of the child's character. Basic cultural characteristics of Pakistan are respect for authority, traditionalism, integrity and enjoyment of life. There is a sense of mistrust in interpersonal relationships. Individuals must always be on guard to protect themselves.

The school is the second agent of the child socialization, but it can play a decisive role in a person's inclination to crime. Problems arise when students are expelled from school for their bad behavior and have no other occupation. Other fact that in Pakistan not all students have the possibility to continue their studies after finishing general schools is also problematic, since the prestige of education is getting higher in society. A conflict may arise between society values and actual possibilities to realize them. Therefore, young people try to gain recognition through other -illegal ways.

Overall analysis of the present study indicates that family occupies an important place among other social groups that socially influence juveniles. Disturbed family functioning is a risk factor in the development of juvenile delinquency. 


\section{REFERENCES}

Alexander, J. F. (1973). Defensive and Supportive Communications in Normal and Deviant Families. Journal of Consulting and Clinical Psychology 44: 223-231.

Norton. In Hill, C.E., (1997). Journal of Counseling Psychology, American Psychological Association, V 01.44, No.1

Becker, W.C. Consequences of Different Kinds of Parental Discipline. In M.L. Hoffman \& L.W.

Hoffman (Eds.), Review of Child Development Research (VoU). New York: Russel Sage Foundation, 1964.

Bratter, T.E.Treating Alienated, Unmotivated Drug Abusing Adolescents. American Journal of Psychotherapy. 1973.9,pg 585,598.

Canter, R (1992). Family Correlates of Male and Female Delinquency. Criminology, 20,149-167.

Cemkovich, S.A, \& Giordano, P.c. (1987). Family Relationships and Delinquency. Criminology, 25, 295-321.

Clark, Richard D. and Glenn Shields. 1997. Family Communication and Delinquency." Adolescence. 32: 81-91.

Dodson, L.S., and Kurpius, D. J. (1977). Family Counseling: A Systems Approach Muncie, in: Accelearted Development.

Dornbusch, S., Cardsmith, J., Bushwall, S., Ritter, P., Liederman, H., Hastorf, A, \& Gross, R. (1985). Single Parents, Extended Households and Control of Adolescents. Child Development, 56, 326341.

Eisenberg, N., \& McNally, S. (1993). Socialization and Mothers' and Adolescents' empathy-related Characteristics. Journal of Research on Adolescence, 3(2), 171-191.

Eisenberg, N., Fabes, R. A, Carlo, G. , Troyer, D., Speer, AL., Karbon, M. „\& Switzer, G. (1992).

The Relation of Maternal Practices and Characteristics to Children's Vicanous Emotional Responsiveness. Child Development, 63 , 583- 602.

Eisenberg, N., Fabes, R. A, \& Murphy, B. C. (1996). Parents' Reactions to Children's Negative Emotions: Relation to Children's Competence and Comforting Behavior. Child Development. 67, 2227-2247.

Faw, T.T., \& Goldsmith, D.F. (1980). Interpersonal Perceptions Within Families Containing Behavior Problems with Adolescents. Journal of Youth \& Adolescence, 9, 553-556.

Feldman. S.S. \& Rosenthal, D.A. (1990). The Acculturation of Autonomy Expectations in Chinese High Schoolers Residing in Two Western Nations. International Journal of Psychology, 25, 259-281. 
Forehand, R.,\& Kotchick, B.A. (1996). Cultural Diversity: A Wake-Up Call for Parent Training.

Behavior Therapy, 27, 187-206 .. In Kendall, P.C. (1997). Journal of Consulting and Clinical Psychology, American Psychological Association, Vol 65, No.6.

Goleman, D.(1995). Emotional Intelligence. New York: Bantam.

Gray-Ray, P., \& Ray, M.C. (1990). Juvenile Delinquency in the Black Community. Youth and Society, 22, 67-84. In Kendall, P.C. (1997). Journal of Consulting and Clinical Psychology, American Psychological Association, Vol 65, No.6.

Hadley, 1A., Holloway, E.L., \& Mallinckrodt, B. (1993). Common Aspects of Object Relations and Self-Representations in off-spring from Disparate Dysfunctional Families. Journal of Counseling Psychology, American Psychological Association, 40,348-356.

Hunter, F. T. (1984). Socializing Procedures in Parent-Child and Friendship Relations During Adolesence . Developmental Psychology, 20, 1052- 1099.

Kim, Jungmeen, E., E. Mavis Hethrington, \& David Rice. (1999). Associations Among Family Relationships, Antisocial Peers, and Adolescents. Externalizing Behaviors: Gender and Family Type Differences. Child Development, 70: 1209-30.

Lamborn, S.D., Dornbusch, S.N., \& Steinberg, L. (1996). Ethnicity and Community Context as Moderators of the Relations Between Family Decision Making and Adolescent Adjustment. Child Development, 67, 283-301. . In Kendall, P.C. (1997). Journal of Consulting and Clinical Psychology, American Psychological Association, Vol 65, No.6.

Laybourn, A. (1986). Traditional Strict Working Class Parenting: An Undervalued System. British Journal of Social Work, 16,625-644.

Laub, J. S., \& Sampson, R J. (1998). Unraveling Families and Delinquency: a Reanalysis of the Glueck data. Criminology, 26, 355-380.

Laybourn, A. (1986). Traditional Strict Working Class Parenting: An Undervalued System. British Journal of Social Work, 16,625-644.

Lytton, H., \& Zwirner, W. (1975). Compliance and its Controlling Stimuli Observed in a Natural Setting.

Socialization, Personality and Social Development (Vol.A, P.1-101).New York.: Wiley.

McMillan, D.W., and Hiltosmith, RW. (1982). Adolescents at Home: An Exploratory Study of the Relationship Between Perception of Family Social Climate, General Wellbeing and Actual Behavior in the Home Setting. Journal of Youth and Adolescence 11: 301-315.

National Conference on Prevention and Control of Juvenile Delinquency. Report on 
Home Responsibility. Washington, DC: Government Printing Office, 1974.

Nye, F.I., (1958). Family Relationships \& Delinquent Behavior, New York: Wiley.

Offer, D., Marohn, R., \& Ostrov, E. (1979). The Psychological World of the Juvenile Delinquent. New York: Basic Books. In Jones, F.R (1985). The Psychology of Human Development. Harper \& Row publishers Inc, New York.

Parish, T.S., Dostal, J.W., \& Parish, 1.G. (1979). Evaluation of Self and Parents as a Function of Intactness of Family and Family Happiness. Adolescence 16: 203-210.

Parke, R.D. (1975). Rules, Roles, and Resistance to Deviation: Recent Advances in Punishment, Discipline and Self Control. In A.D. Pick (Ed.), Minnesota symposia on child psychology, Vol. 8, pp. 111-143). Minneapolis: University of Minnesota Press. In M.H. Bomstein \& M.E. Lamb (1992). Developmental Psychology: An Advanced Textbook ( $3^{\text {rd }}$ Ed.). Lawrence Erlbaum Associates, Inc.

Patterson, G.R, \& Stouthamer-Loeber, M. (1984). The Correlations of Family Management Practices and Delinquency. Child Development, 55, 1299-1307.

Patterson, G.R. (1986). Performance Models for Antisocial Boys, American Psychologist, 41, 432-444.

Patterson, G.R (1975). The Aggressive Child: Victim and Architect of a Coercive System. In L. A.

Hamelynch, L.c. Handy, \& EJ. Mash (Eds.), Behavior Modification and Families. New York:

Brunner / Mazell. In M.H. Bomstein \& M.E. Lamb (1992). Developmental Psychology: An advanced textbook ( $3^{\text {Td }}$ Ed.). Lawrence Erlbaum Associates, Inc.

Richardson, IL, Dwyer, K., McGuigan, k., Hansen, W.B., Dent, C., Johnson, c., Susman, S., Brannon, B., Flay, B. Substance use Among Eighth-Grade Students who Take Care of Themselves after School. Pediatrics 84(1989):556-566.

Rohner, RP. (1975). Parental Acceptance - Rejection and Personality Development. In R.W. Birslin, S.

Bochner, \& WJ. Lonner(Eds.), Cross cultural perspectives on Learning. Beverly Hills: Sage Publications.

Rohner, R.P.\& Rohner, B.C. (1981). Parental acceptance -rejection and parental control: Cross cultural codes. Ethnology, 20, 245-260.

Ryan, RM., \& Lynch, J.H. (1989). Emotional autonomy and development: Revising the vicissitudes of adolescence and young adulthood. Child Development, 60, 34--356.

Sears, RR, Rau, L., \& Alpert, R. (1965). Identification and child rearing. Stanford, CA: Stanford University Press. In Bomstein, M.H., \& Lamb, M.E. (1992). Developmental Psychology: An advanced textbook ( $3^{\text {rd }}$ ed). Lawrence Erlbaum Associates, Inc. 
Shibutani, T. Social Processes: An Introduction to Society. Berkeley and Los Angeles: University of California Press, 1986.

Schwatz,S., Johnson, J.H. Psychopathology of Childhood: A Clinical-Experimental Approach, Second Edition. Pergamon General Psychology Series, 1985, Pg 309.

Shoemaker, R (1990). Theories of delinquency. New York: Oxford University Press.

Smith, C. A., \& Stem, S. B. (1997). Delinquency and antisocial behavior: a review of family processes and intervention research. The Social Service Review, 71, 3 382-420.

Stewart, C.S., \& Zaeng1ein-Senger, M.M. (1984). Female delinquency, family problems, and parental interactions. Social casework: The Journal of contemporary social work, 9, 428-432 .. In Kendall, P.C. (1997). Journal of Consulting and Clinical Psychology, American Psychological Association, Vol 65, No.6.

Snyder, 1, \& Patterson, G.R. (1987). Family interactions and delinquent behavior. In H.C. Quay(Ed.), Handbook of juvenile delinquency (pp.216-243). New York: Wiley.

Tutt, N. Care or custody. New York: AgathonPress, 1974

Wells, L. E., \& Rankin, J. H. (1988). Direct parent controls and delinquency. Criminology, 26, 263285.

Weintraub, KJ., \& Gold, M. (1991). Monitoring and Delinquency: Criminal Behavior and Mental Health, 1, 268-281. . In Kendall, P.C. (1997). Journal of Consulting and Clinical Psychology, American Psychological Association, Vol 65, No.6.

Wilson, H. (1980). Parental Supervision: A Neglected Aspect of Delinquency. British Journal of Criminology, 20, 203-235.

Wright, Kevin N. and Karen E. Wright. 1994. Family Life, Delinquency, and Crime: A Policymakers Guide. Research Summary. Washington DC: OJJDP. 4-21.

Youniss, 1. (1988). Mutuality in Parent-Adolescent Relationships. Washington, DC: William T. grant Commission on work, Family, and Citizenship.

Youniss, 1., \& Smoller, J. (1985). Adolescent Relations with Mothers, Friends, and Fathers. Chicago: University of Chicago Press. 